\title{
INDONESIAN COFFEE IN THE GLOBAL VALUE CHAIN: THE COMPARISON OF GLOBAL PARTNERSHIP SUSTAINABILITY STANDARDS IMPLEMENTATION
}

\author{
Achmad Fadillah*)1, Dikky Indrawan*), and Noer Azam Achsani*) \\ *) School of Business, IPB University \\ Jl. Pajajaran Bogor 16151
}

\begin{abstract}
Global partnerships based on sustainability standards compiled by international NGOs are needed to achieve social, economic and environmentally sustainable development, as well as to deal with global uncertainty in trade and business of agricultural commodities, including coffee in Indonesia. This paper aims to compare the implementation of global partnership standards in coffee between Indonesia and other producer countries. The Study focused on sustainable standard-compliant in coffee such as $4 \mathrm{C}$ and Organic certification standards. Trade and sustainability map tools were described. The findings demonstrate that there were only 8 percent and 9 percent of the Indonesian coffee area certified by $4 \mathrm{C}$ and Organic, respectively. Indonesia placed at number fourth of $4 \mathrm{C}$ implementation in the worldwide after Brazil, Colombia, and Viet Nam. Indonesia is also placed at number fourth of Organic implementation in the worldwide after Mexico, Ethiopia, and Peru. To compete in the potential market, Indonesia's commitment to implement sustainable standard-compliant in coffee is needed. Therefore, Indonesia has to increase the coverage of sustainability standards certified area to meet the global market demand. The government also should implement the right policies and programs to enhance the sustainability compliance of national coffee stakeholders.
\end{abstract}

Keywords: coffee, global trade partnership, sustainability standards, global value chain

\begin{abstract}
Abstrak: Kemitraan global berdasarkan standar keberlanjutan yang disusun oleh LSM internasional diperlukan untuk mencapai pembangunan sosial, ekonomi dan lingkungan yang berkelanjutan, serta untuk mengatasi ketidakpastian global dalam perdagangan dan bisnis komoditas pertanian, termasuk kopi di Indonesia. Makalah ini bertujuan untuk membandingkan penerapan standar kemitraan global dalam kopi antara Indonesia dan negara-negara produsen lainnya. Fokus penelitian pada standar kepatuhan yang berkelanjutan dalam kopi seperti standar sertifikasi 4 C dan Organik. Implementasi digambarkan dengan pendekatan kualitatifdalam rantainilai global berdasarkan pada perangkat peta perdagangan dan keberlanjutan. Temuan menunjukkan bahwa hanya ada 8 persen dan 9 persen dari area kopi Indonesia yang disertifikasi oleh $4 C$ dan Organik, masing-masing. Indonesia menempati urutan keempat implementasi $4 C$ di seluruh dunia setelah Brasil, Kolombia, dan Vietnam. Indonesia juga berada di urutan keempat implementasi Organik di dunia setelah Meksiko, Ethiopia, dan Peru. Untuk bersaing di pasar potensial, komitmen Indonesia untuk menerapkan standar kepatuhan dalam kopi diperlukan. Oleh karena itu, Indonesia harus meningkatkan cakupan area bersertifikasi standar keberlanjutan untuk memenuhi permintaan pasar global. Pemerintah juga harus menerapkan kebijakan dan program yang tepat untuk meningkatkan kepatuhan keberlanjutan pemangku kepentingan kopi nasional.
\end{abstract}

Kata kunci: kopi, kemitraan perdagangan global, standar keberlanjutan, rantai nilai global

\footnotetext{
${ }^{1}$ Corresponding author:

Email: achmadfadillah@apps.ipb.ac.id
} 


\section{INTRODUCTION}

In the trade and business of agricultural commodities, global partnerships based on standards compiled by international NGOs is are needed to achieve social, economic and environmental sustainability. Fair Trade sustainability standards implementation rapidly increase on the global food markets (Raynolds, 2012). However, the partnership by implementing these sustainability standards has not been fully effective in improving the performance of the agricultural sector in Indonesia. Besides, the right business partnership strategy is needed to deal with global uncertainty in trade, industry, and business of agricultural commodities. International business collaboration in commodity development is needed to achieve more sustainable commodities in developing countries (Vermeulen, 2010).

The 17th Sustainable Development Goal (SDG) focuses on strengthening partnerships for sustainable development. This goal means the implementation and revitalization of the global partnership to supports the fulfillment of the sixteen other goals. The consumption growth of coffee with sustainability standards wake up the producers to set their business strategy courses towards sustainable production. Intersectoral partnership in coffee commodity can improve a sustainability of coffee global chain (Bitzer et al. 2008). It also contributes to the 17 th SDGs that aiming to have sustainable consumption and production via partnerships (UN DESA, 2017). Therefore, there was development and co-evolution of commodity value chain and sustainability standards in the global market (Manning et al. 2011).

The sustainability of how such commodities are produced, traded and consumed is at a critical juncture with the outcome likely to be decided within the coming decades (Gardner et al. 2019). Based on ITC (2018), there was significant growth in areas certified by sustainability standards from 2011 to 2016 (Figure 1). There are 14 major voluntary sustainable standards which are initiated by international NGOs including Round Table on Responsible Soy, RSPO, Rainforest Alliance, UTZ, IFOAM - Organics International, Agriculture Network, Forest Stewardship Council, ProTerra Foundation, Better Cotton Initiative, Programme for the Endorsement of Forest Certification, Fairtrade International, GLOBALG.A.P, Cotton made in Africa, BONSUCRO, and 4C. Coffee area with sustainability standards increased by $77.9 \%$. The coffee production area certified by RA, organic, UTZ, Fairtrade International, and 4C) with an average 3.9 million hectares or $35.5 \%$ of the total global coffee area in 2016 (Lernoud et al. 2018). The data of certified area by standard and selected agricultural products in 2016 can be seen in Figure 2.

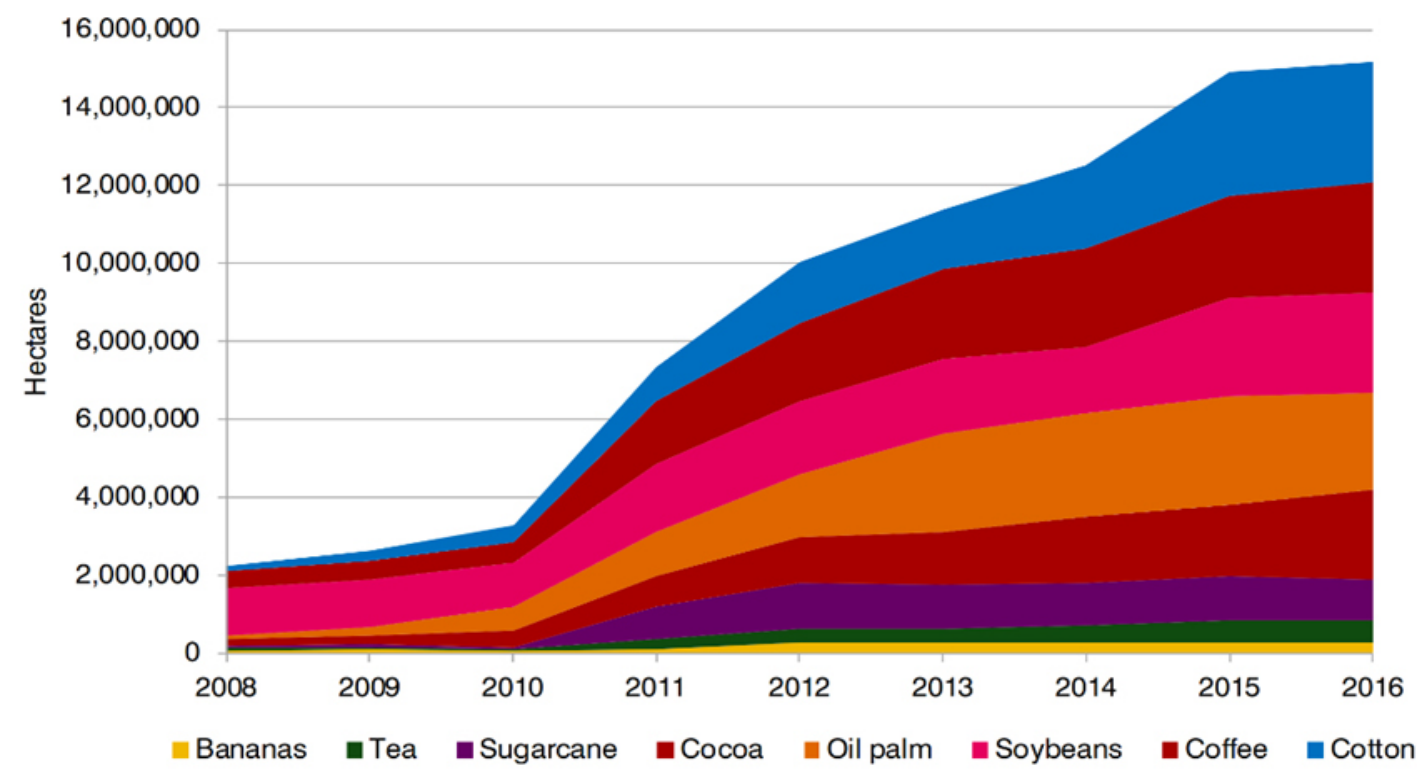

Figure 1. Selected Products Area Growth Certified by Sustainability Standards 2008-2016 (International Trade Center, 2018). 


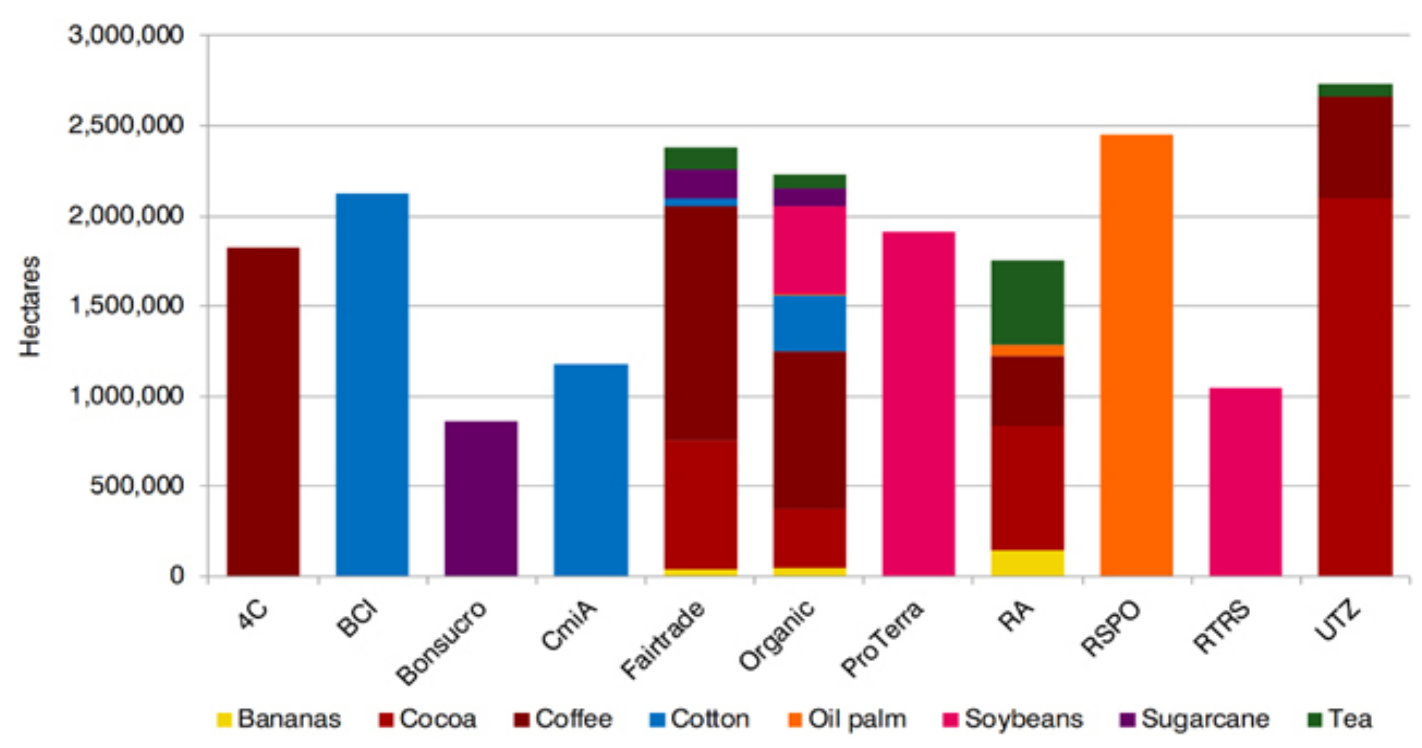

Figure 2. Certified Area by Standard and Selected Agricultural Products 2016 (International Trade Center, 2018)

Brazil, Viet Nam, Colombia, Indonesia, and Ethiopia contributed $69 \%$ of the global coffee production. Brazil, Viet Nam, Colombia, Indonesia, and Ethiopia have increased their production by $16 \%$ during $2011-$ 2016 (FAOSTAT, 2018). In terms of sustainability standards, these five counties also contributed around $71 \%$ of the total coffee area certified by $4 \mathrm{C}$. Based on CAS (2016), 4C certification aims to increase economic, social, dan environmental dimensions of global coffee production and manufacturing based on good agricultural and management practices. $4 \mathrm{C}$ certification has the largest sustainability standards of the coffee area (Figure 3). Arround 1.8 million hectares of global coffee production area certified by $4 \mathrm{C}$ and over 933,950 hectares of global coffee production area certified by Organic as sustainability standards in 2016. The implementation of coffee sustainability standards in Indonesia shows that $4 \mathrm{C}$ certified 150,177 hectares in 2016. Based on Lernoud et al. (2018), Indonesia placed at number fourth in the worldwide after Brazil, Colombia, and Viet Nam. While the implementation of coffee sustainability standards in Indonesia shows that Organic certified 81,750 hectares in 2016. Based on Lernoud et al. (2018), Indonesia also placed at number fourth in the worldwide after Mexico, Ethiopia, and Peru.
However, despite the implementation of sustainability standards by Indonesian coffee, many countries argue that the implementation was not adequate compared to the total production area. This happened because there were many challenges and barriers faced by smallhorders to fulfill specific compliances for sustainability standard or certification (Brandi et al. 2015). As a result, many countries start to impose trade barriers, and it raises uncertainty for coffee production in global trade. The trade barriers imposed on the Indonesian coffee commodity indicate the sustainability standard partnership has not been fully effective in improving trade performance. According to Neilson (2008), Indonesia coffee systems faced many challenges over the last decades in terms of fulfill international agencies standards, company-sepecific needed, country and industry regulations and policies. Therefore, this paper aimed to compare the implementation of global partnership standards in coffee commodity between Indonesia and other main producer countries. We focused on sustainable standard-compliant such as 4C and Organic certification standards. Commodities with sustainable standard-compliant can improve its competitiveness and sustainability performance on the global value chains (Arifin, 2013). 


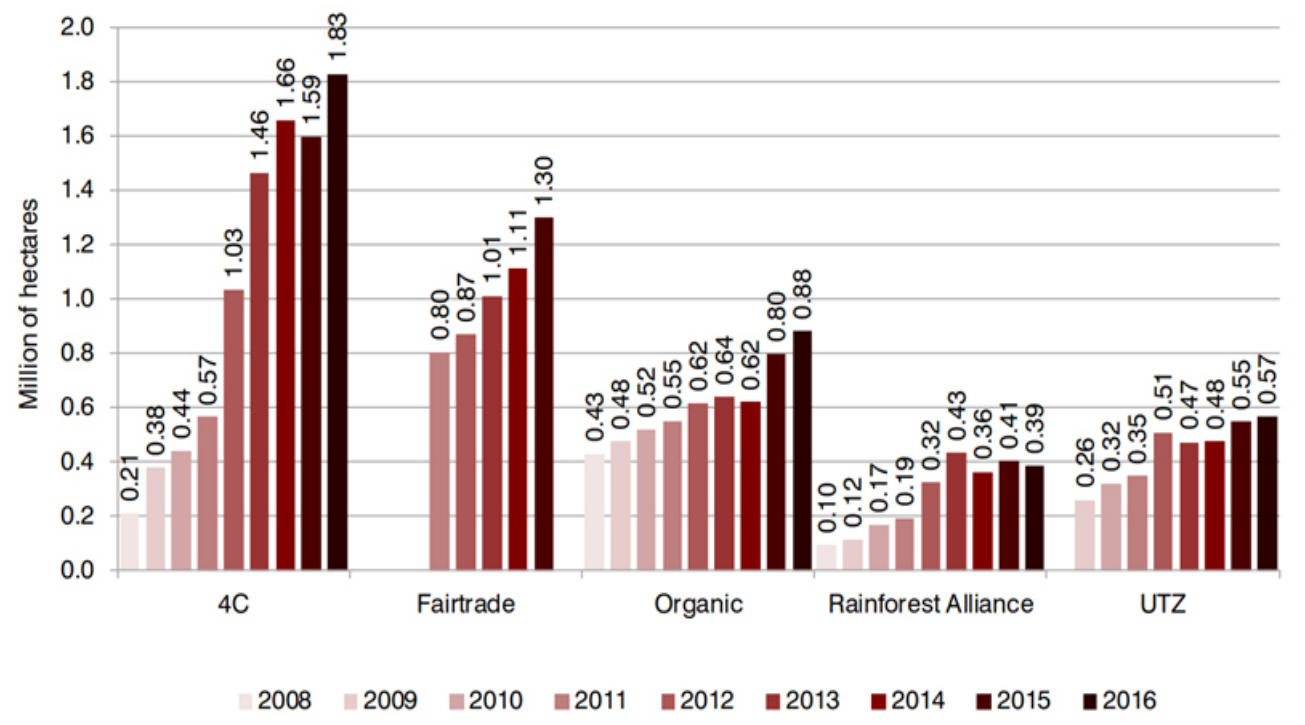

Figure 3. Coffee Production Area by Sustainability Standards 2018-2016 (Lernoud et al. 2018)

\section{METHODS}

Thestudy conducted to assess the sustainability standards applied in Indonesian coffee and several main producer countries. The location of this research was conducted in Indonesia. The study was conducted during AprilMay 2019. The type of data used was secondary data. The main data source in the form of official statistics data comes from the International Trade Center (ITC). The ITC data used to be processed and analyzed was derived from the trade map and sustainability map tools. The data collection technique used were documents and database study of the international trade, especially related to coffee commodities.

Technical analysis of data using four steps, first, the data were collected from the International Trade Centre (ITC). Two main standards were assessed sustainability for its implementation and compliance. Then we performed a descriptive analysis and sustainability map tool database for developing the maps. Finally, we assessed the implementation in the global value chain based on trade and sustainability map tools results.

The research framework was carried out by identifying problems in the implementation of sustainability standards of Indonesian coffee. Furthermore, trade performanceandsustainabilitystandardsimplementation of coffee were analyzed. Coffee global value chains of Indonesia and several main producer countries were compared using maps to get recommendations and managerial implications. Following is the framework for this research (Figure 4).

\section{RESULT}

Figure 5 shows the comparison of $4 \mathrm{C}$ certification between the main producer countries. In 2016, Indonesia had only 8 percent of coffee production certified by $4 \mathrm{C}$ ( 150,013 hectares). It was almost onefifth of Brazil's certified area (737,430 hectares) as the largest coffee-producing country, almost one-half of Columbia's certified area (354,217 hectares) as the second-largest coffee producing country, and almost similar with Vietnam's certified area $(150,177$ hectares $)$ as the closest competitor country in Asia. Figure 5 also shows that Organic had a lower certified area compare to $4 \mathrm{C}$ standards. There were four countries with the largest Organic certified coffee area. The largest area was in Mexico (231,000 hectares), then followed by Ethiopia (159,850 hectares), Peru (81,750 hectares) and Indonesia ( 81,750 hectares).

Based on the global trade coffee performance showed that Brazil, Columbia, Vietn Nam, Ethiopia, and Indonesia are the top five global coffee exporters in 2018 with value exported of USD 4.37 billion, USD 3.26 billion, USD 2.34 billion, USD 8.57 billion, and USD 8.18 billion, respectively (Table 1). Brazil, Viet Nam, Columbia, and Ethiopia are the main competitor for Indonesia in USA and Japan markets. In the European market such as Italy, Indonesia competed directly with Brazil and Columbia as the main competitor. In recent year, Indonesia had a positive growth (15\% p.a.) in the Egypt market from 2014 to 2018. Ethiopia had a higher growth market (10\% p.a.) in the USA than other top five global coffee exporters while Indonesia had 
a negative growth (-4\% p.a.). This situation can be a threat to Indonesian coffee market in the USA as the largest importer country in the worldwide.

The study found that $4 \mathrm{C}$ was used as the main certified standard by coffee importer countries. The results also show Indonesia has many partner countries that imported $4 \mathrm{C}$ and Organic certified coffee in 2018. There were 2 countries have a larger import growth from Indonesia than the import from the rest of the world that serve as Indonesia's main potential market, namely Canada and the Republic of Korea. Currently, the Republic of Korea becomes an emerging market of the global coffee trade. In comparison to another ASEAN country, Viet Nam has significantly higher potential country markets than Indonesia. Viet Nam and Indonesia have almost similar coffee area certified by $4 \mathrm{C}$ around 150,000 hectares in 2016. But, there were 12 countries that had a larger import growth from Viet Nam than the import from the rest of the world.

Other countries from South America were considered as Indonesia's potential competitor in the coffee certified sustainability market namely Brazil and Columbia. Thus, we found that the market prospect for Brazil was the USA, Germany, Italy, Japan, and Belgium. Thus, the market prospect for Columbia was Germany, the USA, Spain, Italy, and Japan. Indonesia competed directly with Brazil and Columbia as the main competitor in the USA, Japan, and Italy coffee markets. These countries were the traditional coffee markets in the world. Brazil becomes a good business model for Indonesia to capture domestic demand and consumption.

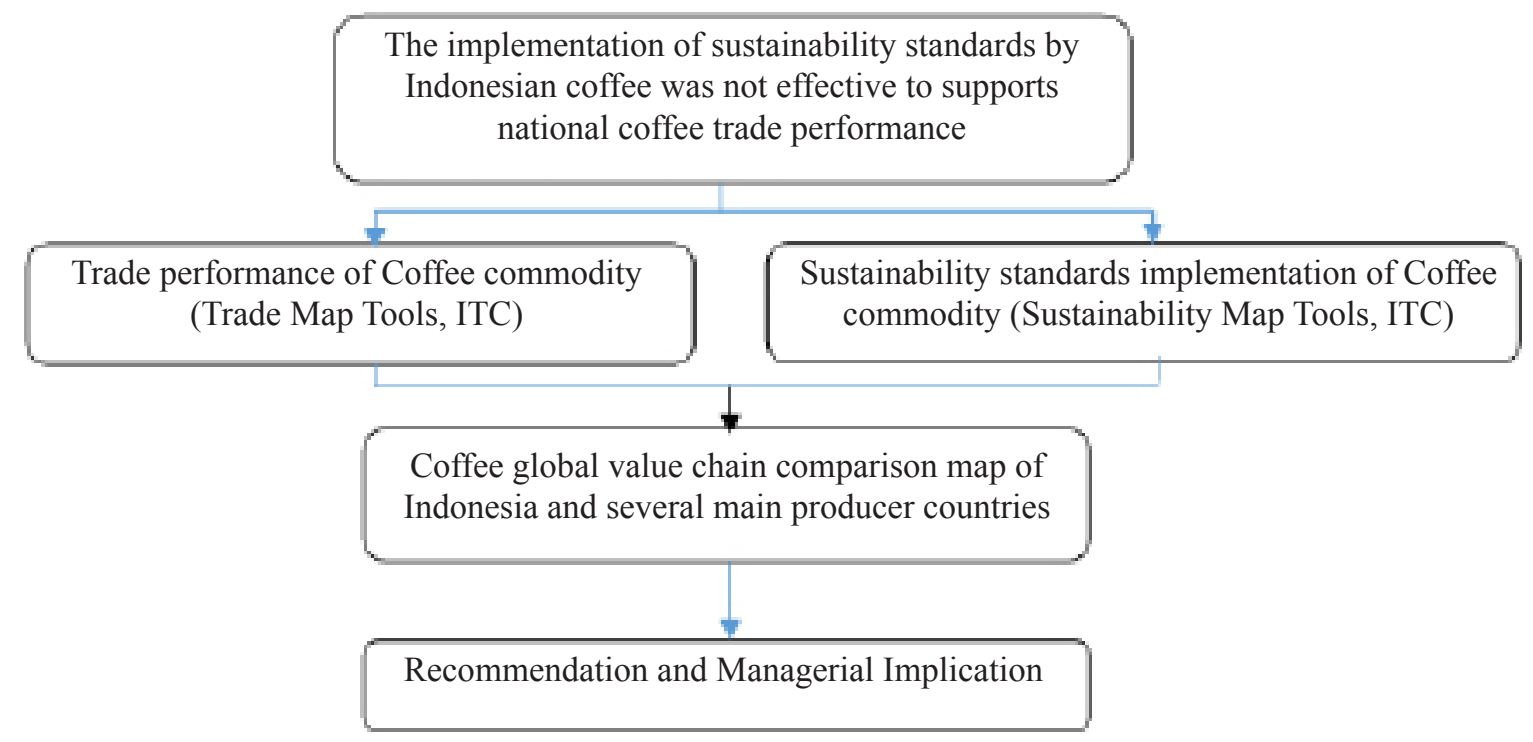

Figure 4. Research framework
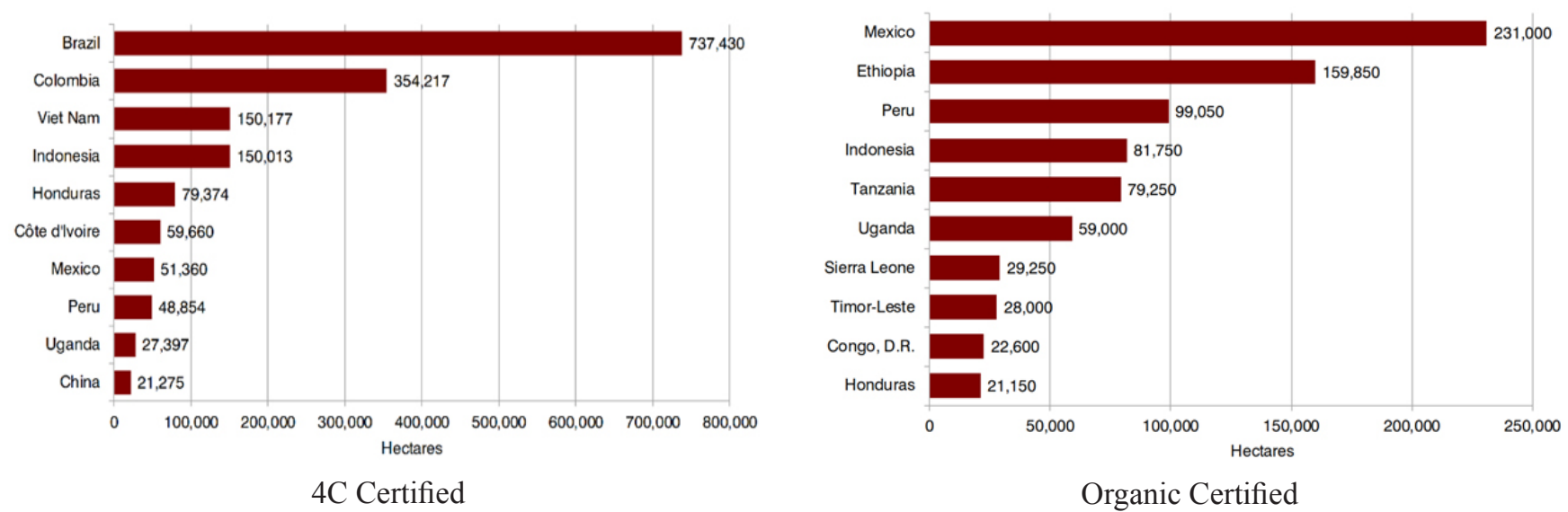

Figure 5. Top 10 Countries by 4C and Organic certified Coffee Area in 2016 (Coffee Assurance Services and FiBL, (2018) 
Table 1. Trade performance comparison of top five global coffee exporters 2018

\begin{tabular}{|c|c|c|c|c|c|c|c|c|}
\hline Exporters & Importers & $\begin{array}{c}\text { Value } \\
\text { exported in } \\
2018 \text { (USD } \\
\text { thousand) }\end{array}$ & $\begin{array}{c}\text { Trade balance } \\
2018 \text { (USD } \\
\text { thousand) }\end{array}$ & $\begin{array}{c}\text { Share in } \\
\text { exports } \\
(\%)\end{array}$ & $\begin{array}{c}\text { Growth in } \\
\text { exported } \\
\text { value between } \\
2014-2018 \\
(\%, \text { p.a. })\end{array}$ & $\begin{array}{l}\text { Ranking } \\
\text { of partner } \\
\text { countries } \\
\text { in world } \\
\text { imports }\end{array}$ & $\begin{array}{c}\text { Share of } \\
\text { partner } \\
\text { countries } \\
\text { in world } \\
\text { imports }(\%) \\
\end{array}$ & $\begin{array}{c}\text { Average } \\
\text { distance } \\
\text { between partner } \\
\text { countries }(\mathrm{km})\end{array}$ \\
\hline \multirow[t]{6}{*}{ Indonesia } & USA & 253,773 & 251,901 & 31 & (4) & 1 & 18 & 6,498 \\
\hline & Japan & 84,375 & 84,306 & 10 & (6) & 6 & 4 & 11,915 \\
\hline & Malaysia & 70,889 & 66,341 & 9 & 5 & 22 & 1 & 5,968 \\
\hline & Egypt & 56,974 & 56,974 & 7 & 15 & 41 & 0 & 7,782 \\
\hline & Italy & 54,025 & 52,650 & 7 & (3) & 4 & 6 & 7,030 \\
\hline & World & 817,790 & 662,012 & 100 & & & & \\
\hline \multirow[t]{6}{*}{ Brazil } & USA & 775,457 & 772,921 & 18 & (11) & 1 & 18 & 6,498 \\
\hline & Germany & 749,407 & 747,876 & 17 & (12) & 2 & 11 & 7,226 \\
\hline & Italy & 461,561 & 455,828 & 11 & (5) & 4 & 6 & 7,030 \\
\hline & Japan & 324,112 & 324,112 & 7 & (11) & 6 & 4 & 11,915 \\
\hline & Belgium & 303,922 & 303,797 & 7 & (14) & 9 & 3 & 6,091 \\
\hline & World & $4,371,253$ & $4,310,264$ & 100 & & & & \\
\hline \multirow[t]{6}{*}{ Viet Nam } & USA & $1,058,089$ & $1,057,961$ & 45 & 1 & 1 & 18 & 6,498 \\
\hline & Japan & 195,241 & 195,241 & 8 & (5) & 6 & 4 & 11,915 \\
\hline & Germany & 181,710 & 181,710 & 8 & (3) & 2 & 11 & 7,226 \\
\hline & Canada & 180,530 & 180,530 & 8 & 1 & 7 & 4 & 4,660 \\
\hline & Belgium & 125,268 & 125,268 & 5 & (14) & 9 & 3 & 6,091 \\
\hline & World & $2,335,423$ & $2,239,362$ & 100 & & & & \\
\hline \multirow[t]{6}{*}{ Columbia } & Germany & 513,274 & 512,609 & 16 & 1 & 2 & 11 & 7,226 \\
\hline & USA & 413,518 & 408,797 & 13 & (1) & 1 & 18 & 6,498 \\
\hline & Spain & 269,009 & 269,007 & 8 & - & 10 & 3 & 5,520 \\
\hline & Italy & 258,395 & 257,817 & 8 & 1 & 4 & 6 & 7,030 \\
\hline & Japan & 189,276 & 189,274 & 6 & 5 & 6 & 4 & 11,915 \\
\hline & World & $3,261,049$ & $3,202,570$ & 100 & & & & \\
\hline \multirow[t]{6}{*}{ Ethiopia } & USA & 142,121 & 142,121 & 17 & 10 & 1 & 18 & 6,498 \\
\hline & Germany & 137,044 & 137,044 & 16 & 2 & 2 & 11 & 7,226 \\
\hline & Saudi Arabia & 126,273 & 126,273 & 15 & - & 25 & 1 & 3,221 \\
\hline & Japan & 83,760 & 83,760 & 10 & 1 & 6 & 4 & 11,915 \\
\hline & $\begin{array}{l}\text { Republic of } \\
\text { Korea }\end{array}$ & 48,496 & 48,496 & 6 & 14 & 12 & 2 & 11,131 \\
\hline & World & 856,929 & 856,859 & 100 & & & & \\
\hline
\end{tabular}

Source: International Trade Center (2018)

Indonesia and Ethiopia have almost similar value exported coffee in 2018 (around USD 8 billion). There were 13 countries had a larger import growth from Ethiopia than the import from the rest of the world. Ethiopia also had a significant growth in exported value to emerging market such as the Republic of Korea (14\% p.a) from 2014 to 2018. Meanwhile, Ethiopia still keeps its potential trade in the traditional market such as the USA with growth in exported value around $10 \%$. The comparison of coffee trade performance of top five global exporters in 2018 can be seen in Figure 6.
Global coffee production and consumption have become an important issue in recent years. Coffee trade competitiveness compares to other countries has been linked to coffee industry growth in the world. As sustainability standard, 4C was introduced by coffee stakeholders to improve the coffee profile. Indonesia tries to promote and advocate the coffee by endorsing 4C and Organic certification. However, the effort may not meet the international market demand, especially from the USA, Japan, and Italy. Despite the fact of Indonesia was able to be placed as the fourth largest certified area by $4 \mathrm{C}$ and Organic, the sustainability practices via $4 \mathrm{C}$ 
and Organic are still low compared to the total coffee production area. Therefore, the effort is not sufficient, especially with the recent USA and Japan markets showed that the negative trends ( $-4 \%$ p.a and $-6 \%$ p.a., respectively). It shows that the voluntary partnership is not working properly for Indonesia. As a result, it weakening Indonesia's coffee trade performance in the global value chain.

Since the sustainability mapping shows that Indonesia directly competes with Brazil, Columbia, Viet Nam, and Ethiopia in the Global Coffee Value Chain. Indonesian coffee industry development is required to meet the rising demand for coffee and to compete with these countries in the global value chain of coffee. There was still strong demand in many countries, especially from traditional markets (Japan, USA, France, Italy, and Germany). According to Sänger (2018), there was also big opportunity for further coffee demand in the emerging markets such China, Turkey, Russia, and South Korea. So, Indonesia should enhance its certified coffee area with sustainability standards. Indonesia also should focus on the biggest potential trade from emerging markets and domestic demand.

\section{Managerial Implications}

Therefore, for managerial implication Indonesia has to increase the coverage of sustainability standards certified area to meet the global market demand. The government also should implement the right policies and programs to enhance the sustainability compliance of national coffee stakeholders.
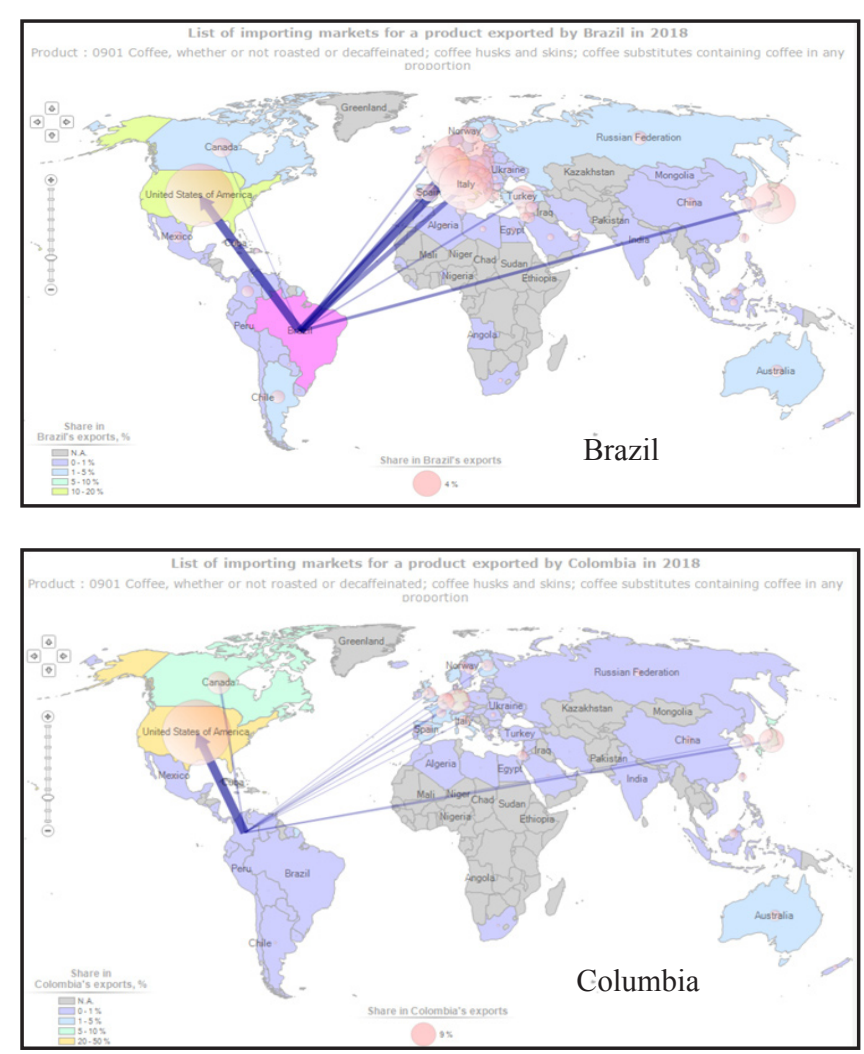
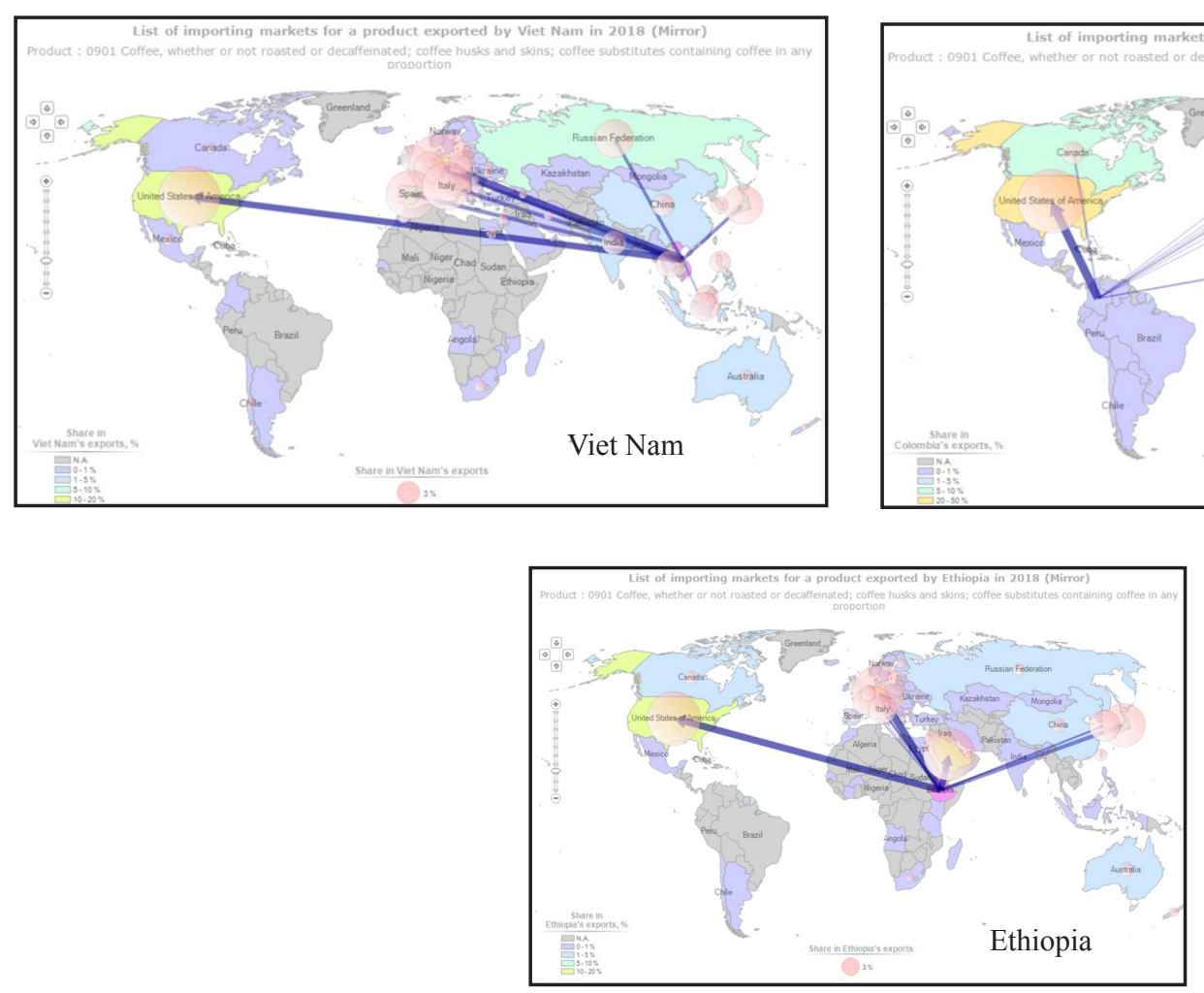

Figure 6. Comparison of coffee trade performance of top five global exporters in 2018 


\section{CONCLUSIONS AND RECOMMENDATIONS}

\section{Conclusions}

Based on the global trade coffee performance showed that Brazil, Columbia, Viet Nam, Ethiopia, and Indonesia are the top five global coffee exporters in 2018 with value exported of USD 4.37 billion, USD 3.26 billion, USD 2.34 billion, USD 8.57 billion, and USD 8.18 billion, respectively. The findings also demonstrate that there were only eight percent and nine percent of the Indonesian coffee area certified by $4 \mathrm{C}$ and Organic, respectively. Indonesia placed at number fourth of $4 \mathrm{C}$ implementation in the worldwide after Brazil, Colombia, and Viet Nam. Indonesia also placed at number fourth of Organic implementation in the worldwide after Mexico, Ethiopia, and Peru. Despite the fact of Indonesia was able to be placed as the fourth largest certified area by $4 \mathrm{C}$ and Organic, the sustainability practices via $4 \mathrm{C}$ and Organic are still low compared to the total coffee production area. It shows that the voluntary partnership is not working properly for Indonesia. As a result, it weakening Indonesia's coffee trade performance in the global value chain.

\section{Recommendations}

In the future, the coffee market is estimated to be increased especially in emerging markets (Republic of Korea, Rusia, Turkey, and China). The only way that Indonesia's coffee industry to compete in this potential market, the commitment to implement sustainable standard-compliant in coffee is needed. As a consequent to meet the global market demand especially in traditional markets (Japan, USA, France, Italy, and Germany), Indonesia has to increase the coverage area certified by $4 \mathrm{C}$ and Organic.

\section{REFERENCES}

Arifin B. 2013. On the Competitiveness and Sustainability of the Indonesian Agricultural Export Commodities. ASEAN Journal of Economics, Management and Accounting 1(1): 81-100.

Bitzera V, Francken M, Glasbergena P. 2008. Intersectoral partnerships for a sustainable coffee chain: Really addressing sustainability or just picking (coffee) cherries?. Global Environmental Change. Volume 18, Issue 2, May 2008, Pages 271-284. https://doi.org/10.1016/j. gloenvcha.2008.01.002.

Coffee Assurance Services (CAS). (2018). Top 10 Countries by 4C Certified Coffee Area in 2016.

FAOSTAT. 2018. FAOSTAT Database. Available at: http://www.fao.org/faostat/en/

Gardner TA et al. 2019. Transparency and sustainability in global commodity supply chains. World Development 121: 163-177. https://doi. org/10.1016/j.worlddev.2018.05.025.

Lernoud J et al. 2018. The State of Sustainable MarketsStatistics and Emerging Trends 2018. Geneva; ITC.

Manning S et al. 2011. National contexts matter: The co-evolution of sustainability standards in global value chains. Ecological Economics 83:197-209. https://doi.org/10.1016/j.ecolecon.2011.08.029.

Neilson J. 2008. Global Private Regulation and ValueChain Restructuring in Indonesian Smallholder Coffee Systems. World Development 36(9): 1607-1622. https://doi.org/10.1016/j. worlddev.2007.09.005

Raynolds LT. 2012. Fair Trade: Social regulation in global food markets. Journal of Rural Studies. 28(3):276-287.https://doi.org/10.1016/j. jrurstud.2012.03.004.

Research Institute of Organic Agriculture (FiBL). (2018), Top 10 Countries by Organic Certified Coffee Area in 2016.

Sänger C. 2018. State of the global coffee market. United Nations Conference on Trade and Development: 10th Multi-Year Expert Meeting on Commodities and Development. 25-26 April 2018, Geneva.

[UN DESA] United Nations Department of Economic and Social Affairs. 2017. Goal 17 Sustainable Development Knowledge Platform. https:// sustainabledevelopment.un.org/sdg17. [22 Jul 2019].

Vermeulen, W.J.V. 2010. Sustainable supply chain governance systems: conditions for effective market based governance in global trade. Progress in Industrial Ecology - An International Journal 7(2):138-168. https://doi.org/10.1504/ PIE.2010.036046. 